\title{
“一带一路”视角下地方应用型本科院校来华留学生招生品牌营 销路径一以桂西北高校为例
}

\section{宋友开王文珍}

桂林旅游学院

DOI:10.32629/er.v3i5.2709

[摘 要] 近年来,来华留学生的规模逐年扩大,专业和学习形式也日趋丰富,呈现出学历生后来居上、自费生比例占多等特点。H.C. 学院作为一 所地方性 “运用型” 本科院校,地处有丰富自然文化优势的桂西北地区,但来华留学工作却相对滞后, 本文通过对全国和广西壮族自治区来华留 学情况和现状进行分析,对桂西北 “运用型” 本科院校的来华留学招生机制、扩大规模策略、优化结构、提升教学质量等方面进行探讨,提出可 持续、全方位的来华留学招生工作策略。

[关键词] “一带一路”战略; 地方 “运用型” 本科; 教育品牌营销路径

习近平总书记在十九大报告中提出: 我国开发的深度和广度会不断的 深化与扩展！继续稳步推进 “一带一路” 战略的实施, 实现 “一带一路” 沿线国家共赢发展。高等教育的来华留学工作首当其冲, 来华留学工作是 “一带一路” 战略经济合作和人文交流的助推器, 既能培养大批建设项目 所需的专业人才, 又能促进中华语言文化与沿线国家人文相通。高等教育 国际化的趋势下，广西既是中国-东盟开放交流的 “桥头堡”, 又占据着“一 带一路”海上丝绸之路关键节点的区位优势。桂西北地区坐拥丰富的民族 文化和自然文化资源, 地方性 “应用型” 本科院校, 拓宽深化来华留学生招 生渠道, 扩大来华留学生规模、丰富来华留学生学习层次和专业, 为国家 “一带一路” 战略培养输送人才成为必然。

\section{1 “一带一路”沿线国家来华留学生教育发展现状及特点}

据教育部统计, “2018年, 共有来自196个国家和地区的49.22万名留学 生来华留学, 中国成为亚洲最大留学目的国。其中, “一带一路” 沿线国家 留学生 31.72 万人, 占总人数的 $64.85 \%$, 增幅达 $11.58 \%$ 。” ${ }^{[1]}$ 。近年来, 丝路 沿线国家来华留学生的数量不断提升, 生源国持续增加, 学习模式和层次 不断多样化, 学习专业的范围持续扩大, 自费生为主要类别。特点主要包 括: 从绝对数量看, 留学生人数越来越多, “一带一路” 国家2004年来华留 学生人数为 24896 人, 2010 年突破 11 万, 2016 年突破 20 万, 2018 年突破 30 万, 达到 31.72 万人。沿线国家来华留学生的增长速度远远高于全国的增长速 度, 其规模扩张最为迅猛, 成为我国留学教育的新亮点。“一带一路” 沿线 共65个国家, 至2017年, “一带一路” 所有国家均有学生来华留学。在系列 国家 “一带一路” 教育政策的激励下, 沿线国家将会是来华留学生教育发 展主要动力, 成为来华留学最后重要的生源地。学历生多、专业学科更 加合理, 层次越来越高、经费来源以自费为主, 学习中文为主的专业趋势 被打破, 学生学习专业学科更加全面、合理, 2016年来华留学学生学习中 文的人数占比总留学生人数的 $38.2 \%$, 而 2012 年学习中文的学生占当年 来华留学人数的 $53.5 \%$, 学习中文人数 2016 年比 2012 年比例下降 $15.3 \%$ 。 2016年, 学习理工科、工程、教育和农学学生数量比 2012 年增加超过 $100 \%$, 经济、西医、文学、法学、管理等学科学生数量增幅均超过 $50 \%$, 其中, 占比增长幅度最快的为工科, 2016 年比 2012 年增加了 5.2 个百分点, 西 医、工科、经济和管理是学历生就读人数最多的四个学科, 其次为汉语 言专业, 排第五。2017年共有来自180个国家的5.86万名中国政府奖学金 生在华学习, 占总数的 $11.97 \%$ 。

\section{2 “一带一路” 沿线国家人才与高等教育需求}

“一带一路”建设是以经济贸易为主要载体、以互联互通为核心概念
以互利共赢为基本目的的跨国战略合作设想, 沿途连通亚洲、非洲、欧洲 等 64 个国家, 目前总人口约 44 亿人, 经济总量约 21 万亿美元, 分别约占全球 的63\%和 $29 \%$ 。“带一路” 巨大的基础设施建设, 需要土木工程、机械电气 工程等专业管理人才。据亚洲开发银行的评估报告显示, 2010 2020年, 亚洲各国累计需要投入 7.97 万亿美元用于基础设施的建设与维护, 涉及 989 个交通运输和 88 个能源跨境项目。 ${ }^{[2]}$ “一带一路” 沿线有 64 个国家, 中 国与 “一带一路” 沿线国家的经贸合作, 催生了当地中国语言文化人才的 培养需求, 急需大量通晓中国语言文化的当地人才。随着经济生活水平的 不断提高, “一带一路” 沿线对医疗人才的需求越来越大。由此可见, “一 带一路” 沿线国家需要的人才涵盖: 交通、信息、能源基础设施人才、贸 易与投资经营人才、语言文化人才、医疗人才等。

3 桂西北地方 “应用型” 本科院校来华留学教育概况 表1２013年至2019年H. C. 学院在校来华留学生

\begin{tabular}{|c|c|c|c|}
\hline 年份 & 总人数 & 国别 & 就读形式 \\
\hline 2013 & 4 & 泰国 & 短期 \\
\hline 2014 & 8 & 泰国 & 短期 \\
\hline 2015 & 15 & 泰国 & 短期 \\
\hline 2016 & 9 & 泰国 & 短期 \\
\hline 2017 & 62 & $\begin{array}{r}\text { 泰国、几内亚、尼日利亚、乌兹别克斯坦、巴基斯坦等 } \\
\text { 孟 }\end{array}$ & 长期 \\
\hline 2018 & 103 & $\begin{array}{r}\text { 泰国、塔吉克斯坦、乌兹别克斯坦、埃塞俄比亚、巴基斯 } \\
\text { 坦、孟加拉国等 }\end{array}$ & $\begin{array}{c}\text { 四年学历生、一年语 } \\
\text { 言生 }\end{array}$ \\
\hline 2019 & 135 & $\begin{array}{c}\text { 孟加拉国、巴布新几内亚、埃塞俄比亚、蒙古国等 } 25 \text { 个 } \\
\text { “带一路” 国家 }\end{array}$ & $\begin{array}{c}\text { 学历生 } 108, \text { 一年期 } \\
\text { 语言生 } 27 \text { 名 }\end{array}$ \\
\hline
\end{tabular}

从表中可以看出自从2013年迎来首批来华留学生以来, 桂西北 “应用 型”本科院校, 来华留学生人数从 4 个增加到了 2019 年的 135 名, 生源国从泰 国单一国家增加到几内亚、尼日利亚、巴基斯坦、孟加拉国、乌兹别克斯 坦、坦桑尼亚等 25 个 “一带一路” 国家。虽然从生源地到数量都有所扩大, 但形式依然严峻, 主要原因有三:一是来华留学生招生渠道单一, 当前来华 留学生是以校际交换学生为主的招生模式, 若校际交流合作能长期稳定, 生源便相对稳定, 但是每年招收的交换生多为中文短期进修生, 少则一个 月, 多则一年, 始终只是停留在语言培训的简单层面, 造成留学生教育专业 学科层次的单一; 二是学习项目单一, 自2013年第一批4名来自泰国的短期 汉语语言交换生开始以来, 直到2016年, 开设的来华留学项目仅为商务汉 语言学习, 学历生学习项目专业单一, 2017年9月才实现学历生零的突破, 
招生的专业仅包括商务汉语、商务英语两个语言类专业, 2019年达到了 135 名; 三是国际化师资力量不足, 具有国际化视野和能有英文授课的师资力 量不能满足来华留学生人数增加的需求。

\section{4 地方 “应用型” 本科院校扩大来华留学招生的路劲}

4. 1 内向路径

(1) 根据学校的专业学科优势, 结合地方经济发展, 开发联合培养项目, 并努力实现不同高校间课程学分的相互认可, 培养复合型人才, 加强不同 学科的交叉与融合, 打破现有学科的分类布局, 整合外语、汉语言文学、经 济、旅游及理工等已有学科专业, 开发跨专业的“一带一路”学科, 尝试“外 语 $+X$ (旅游管理、机械工程、市场营销、贸易经济等专业) ” 人才培养模 式。将 “一带一路” 建设背景、实施重点、合作机制、规则标准以及 “一 带一路”沿线国家历史文化、社会经济、民族宗教等通识内容, 并努力将 相关要素渗透在各学科的专业教育内容之中, 建设服务 “一带一路” 建设 的英语授课体系和学位课程, 打造来华留学生教育精品课程和品牌专业, 让学生来华留学 “学得好”、回国 “用得上”。

(2) 提高夯实来华留学生管理服务水平, 针对留学生源来自不同国家、 文化背景、生活环境、风俗习惯, “提高留学生管理服务水平, 除高水平的 师资外, 还需要一批工作认真细致、具有爱心、耐心, 富有奉献精神、熟悉 国家相关政策、具有国际视野的留学生管理队伍” ${ }^{[3]}$, 成为留学生的贴心 人, 他们日常生活中的好朋友。对他们出现的困难及时予以帮助, 对不良行 为及时予以制止。

(3) 设立 “一带一路” 奖学金, 吸引优质生源, 立足于主动服务和融入 国家 “一带一路” 战略, 在已有奖学金及学费政策的基础上, 建立来华留学 “一带一路”奖学金, 针对申请到我校就读的优秀来华留学本科生, 学习时 间超过半年的中国文化以及汉语培训的短期学习优秀学生、部分与我校合 作的高校优秀交换生给予 “一带一路” 校级奖学金, 免交学费; 对学习成 绩优秀的留学生颁发 “一带一路” 校长奖学金, 吸引优质生源。

4. 2 外延路径

(1) 拓宽来华留学教育招生渠道, 来华留学招生渠道是重要短板, 依法 选择专业的来华留学中介, 拓展来华留学生申请来校学习渠道。高等教育国 际化趋势, 催生了一批专业来华留学中介机构, 有一批专业的生源国工作人
员, 熟知所在国家的学生需求, 可靠性大, 能提供比较稳定的来华留学生源。

(2) 开展多层次海外办学, 拓展国际合作院校, 建立双向、多国交流的 国际合作项目, 提高高等教育国际化水平, 提升学校来华留学国家化水平, 建立中加合作办学项目, “H. C. 学院+加拿大曼尼托巴大学、温尼伯格大 学”, $3+1, 、 2+2$ 项目, 中泰合作办学项目, H. C. 学院 $3+1 、 2+2$ 项目。来校学 习的优秀留学生, 获得到加拿大合作高校或者东盟国家高校的学习机会。 “一带一路” 建设为我国高校 “走出去” 开展多层次海外办学提供了难得 的历史机遇。地方 “应用型” 本科院校应利用好我国高等教育的各种资源 和渠道, 加大境外办学力度, 在沿线国家共建大学或开办分校, 同国外学府 合作授予双重学位, 传播中国文化, 扩大中国高校的影响力。目前, 哈萨克 斯坦、巴基斯坦、约旦、埃及等十多个 “一带一路” 沿线国家已向中国发 出了赴境外办学的邀请。其中约旦和埃及等国家希望中国的应用技术学校 和相关专业赴当地办学。 ${ }^{[3]}$

\section{5 小结}

在教育全球化以及高等教育国际化趋势下, 来华留学生教育是挑战, 更是机遇, 桂西北地区地方 “运用型” 本科来华留学教育大有可为, 来华留 学生招生与教育是一项立体多维度工作, 涵盖学校专业学科建设质量、高 等教育服务质量、校园设施、文化氛围与人文关怀等。确立 “外向型” 来 华留学招生教育策略, 内修学校专业学科与师资力量、学校教学设施建设, 以国际化包容性的视野、高质量的教育, 外修稳定可高的多渠道全方位的 来华留学招生体系, 桂西北地方性 “应用型” 本科可实现来华留学在 “质” 和 “量” 都得到可持续发展。

\section{[参考文献]}

[1]2016年度我国来华留学生情况统计[DB/OL].(2017-3-1)[2018-3-20] http://www.moe.gov.cn/.

[2]篗振元.“一带一路”建设与国家教育新使命 $[N]$. 光明日报,2015-8-13(11).

[3]贺继军.地方高校留学生教育的问题及对策[J].宁波: 浙江万里学院 学报,2009(11):64.

\section{项目基金:}

2020 年度桂林旅游学院教育教学改革研究项目阶段性成果(项目 编号：2020XJJG006)。 